\title{
The value of internal jugular vein collapsibility index in sepsis
}

\author{
Murat Haliloğlu, M.D., Beliz Bilgili, M.D., Alper Kararmaz, M.D., İsmail Cinel, M.D.
}

Department of Anesthesiology and Reanimation, Marmara University Faculty of Medicine, İstanbul-Turkey

\begin{abstract}
BACKGROUND: Rapid, accurate, and reproducible assessment of intravascular volume status is crucial in order to predict the efficacy of volume expansion in septic patients. The aim of this study was to verify the feasibility and usefulness of the internal jugular vein collapsibility index (IJV-Cl) as an adjunct to the inferior vena cava collapsibility index (IVC-Cl) to predict fluid responsiveness in spontaneously-breathing patients with sepsis.
\end{abstract}

METHODS: Three stages of sonographic scanning were performed. Hemodynamic data were collected using the Ultrasonic Cardiac Output Monitor IA system (Uscom, Ltd., Sydney, NSW, Australia) coupled with paired assessments of IVC-Cl and IJV-Cl at baseline, after passive leg raise (PLR), and again in semi-recumbent position. Fluid responsiveness was assessed according to changes in the cardiac index $(\mathrm{Cl})$ induced by PLR. Patients were retrospectively divided into 2 groups: fluid responder if an increase in $\mathrm{Cl}(\Delta \mathrm{Cl}) \geq \mathrm{I} \%$ was obtained after PLR maneuver, and non-responder if $\Delta \mathrm{Cl}$ was $<15 \%$.

RESULTS: Total of 132 paired scans of IJV and IVC were completed in 44 patients who presented with sepsis and who were not receiving mechanical ventilation (mean age: $54.6 \pm 16$.l years). Of these, $23(52.2 \%)$ were considered to be responders. Responders had higher IJV-Cl and IVC-Cl before PLR maneuver than non-responders $(\mathrm{p}<0.00 \mathrm{I})$. IJV-Cl of more than $36 \%$ before PLR maneuver had $78 \%$ sensitivity and $85 \%$ specificity to predict responder. Furthermore, less time was needed to measure venous diameters for IJV-Cl (30 seconds) compared with IVC-Cl (77.5 seconds; $\mathrm{p}<0.00 \mathrm{I})$.

CONCLUSION: IJV-Cl is a precise, easily acquired, non-invasive parameter of fluid responsiveness in patients with sepsis who are not mechanically ventilated, and it appears to be a reasonable adjunct to IVC-Cl.

Keywords: Collapsibility index; fluid therapy; inferior vena cava; internal jugular vein.

\section{INTRODUCTION}

Sepsis is associated with decreased effective blood volume, and fluid resuscitation is usually recommended to increase cardiac output and improve tissue hypoperfusion. ${ }^{[1]}$ However, studies have shown a relationship between positive fluid balance and mortality in patients with sepsis. ${ }^{[2]}$ Therefore, rapid, accurate, and reproducible assessment of intravascular volume status is crucial in order to predict the efficacy of volume expansion..$^{[3]}$

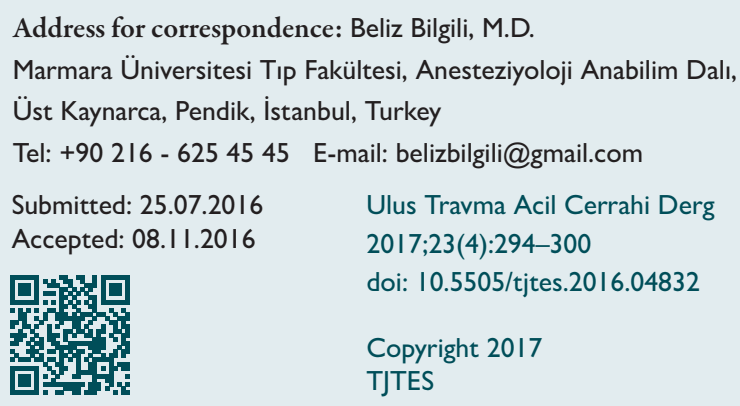

The inferior vena cava collapsibility index (IVC-CI) has been shown to correlate with both clinical and invasive assessment of intravascular volume status and has become increasingly popular. ${ }^{[4]}$ It is very easy to record and has a short learning curve. However, IVC measurements are not possible in $10 \%$ to $15 \%$ of patients because of abdominal distension, ascites, bowel gas, tissue edema, complex abdominal wounds, or morbid obesity. ${ }^{[5]} \mathrm{A}$ body of evidence indicates that extrathoracic veins can reflect intrathoracic venous pressure and volume changes. ${ }^{[6]}$ Based on this association, hypothesis of this study was that internal jugular vein collapsibility index (IJV-Cl) could be an alternative sonographic option to IVC-CI. Prospective examination of the efficacy of the $\mathrm{JV}-\mathrm{Cl}$ as an alternative in the absence of adequate IVC visualization was performed.

\section{MATERIALS AND METHODS}

After receiving institutional review board approval, a prospective, observational clinical trial was conducted in the surgical intensive care unit (SICU) at a university hospital. Marmara University ethics committee approval (No: 09.2015.288) was granted, written informed consent was obtained from the pa- 
tients, and the study was conducted in accordance with the Declaration of Helsinki, including current revisions and Good Clinical Practice guidelines. Hemodynamic data obtained from 44 patients presenting sepsis, according to the definition of and treated following the indications of Surviving Sepsis Campaign Guidelines. ${ }^{[1]}$ All patients were enrolled within 6 hours of the time of admission to SICU and were not receiving mechanical ventilation. The patients signed informed consent form prior to initiation of study-related activities.

Collected data included patient demographics (age, sex), Sequential Organ Failure Assessment (SOFA) score, Acute Physiology And Chronic Health Evaluation (APACHE II) score, laboratory values, hemodynamic parameters, and sonographic measurements of IVC and IJV collapsibility.

Exclusion criteria were age $<18$ years, pregnancy, severe aortic stenosis, irregular ventricular rhythm (atrial fibrillation or frequent premature ventricular contractions), or any contraindication to performing passive leg raise (PLR) (intracranial hypertension, intraabdominal hypertension, body mass index $>40 \mathrm{~kg} / \mathrm{m}^{2}$, deep venous thrombosis, use of venous elastic compression stockings, or limb and pelvic fracture).

Hemodynamic data and paired sonographic measurements of IVC and IJV were collected simultaneously; measurements were performed by single operator. All patients in this study underwent serial, simultaneous assessments of IVC-Cl and IJV$\mathrm{Cl}$ using Philips EPIQ 5 ultrasound system (Philips Healthcare, Inc., Andover, MA, USA). Ultrasonographic examination was performed with standard curvilinear phased array transducer via initial B-mode paramedian longitudinal window of the IVC just proximal to the junction of the hepatic veins that lie approximately $0.5 \mathrm{~cm}$ to $3 \mathrm{~cm}$ proximal to the right atrium. ${ }^{[4]} \mathrm{JV}$ was visualized with high-frequency linear array transducer via cross-sectional B-mode window of the short axis of the vessel at the level of the cricoid cartilage and recognized by compression, color Doppler, and pulsed-wave Doppler sampling. In order to avoid changes in vein diameter unrelated to respiratory variation, minimal pressure was applied to the probe to ensure that venous occlusion did not occur. ${ }^{[7]}$ Dynamic diameter changes of the target vein were recorded using $M$ mode to measure maximum and minimum dimensions over 20 -second period of spontaneous respiration. Vein collapsibil- ity was calculated using the following formula: collapsibility (\%) $=($ max diameter - min diameter $) /$ max diameter ${ }^{[8,9]}$ For each scan, time to data acquisition was defined as time from probe placement to vessel measurement recording. Hemodynamic data were collected using Ultrasonic Cardiac Output Monitor (USCOM) IA system (Uscom Ltd., Sydney, NSW, Australia), coupled with paired assessments of IVC-Cl and $\mathrm{IJ}-\mathrm{Cl}$.

The study protocol was performed in 3 sequential stages. Baseline parameters were recorded with the patient in semirecumbent position. Next, PLR maneuver was performed by placing the patient in supine position and simultaneously raising the patient's legs to $45^{\circ}$, and after I minute, second measurement was recorded. Third measurement was performed 2 minutes after the patient had been moved back to semi-recumbent position in order to check that measured parameters had returned to baseline. The study protocol is shown in Figure I.

Fluid responsiveness was assessed through changes in cardiac index $(\mathrm{Cl})$ induced by PLR. Patients were retrospectively divided into 2 groups: fluid responders, if increase in $\mathrm{Cl}(\Delta \mathrm{Cl})$ of $\geq 15 \%$ was obtained after PLR maneuver, and non-responders if $\Delta \mathrm{Cl}$ was $<15 \%$, as previously described. ${ }^{[10]}$

\section{Statistical Analysis}

R v.2I5.3 (R Core Team, 20I3; R Foundation for Statistical Computing, Vienna, Austria) software was used to perform statistical analyses. Data were reported as mean, standard deviation, median, first quartile, third quartile, frequency, percentage, minimum and maximum. Student's t-test was used to assess difference of normally distributed variables between the 2 groups. Mann-Whitney $U$ test was used to test difference of non-normally distributed variables between groups. Paired t-test was applied to analyze difference between IVC and IJV values. Receiver operating characteristic (ROC) curves were constructed, sensitivity and specificity of variables were calculated for various values, and value with highest Youden index value was taken as cut-off point. Pearson's correlation coefficient was used to test association between variables. Paired, concurrent measurements of $\mathrm{IVC}-\mathrm{Cl}$ and $\mathrm{IJV}-\mathrm{Cl}$ were analyzed using correlation coefficient and Bland-Altman bias plot. Statistical significance was defined as $\mathrm{p}<0.05$.

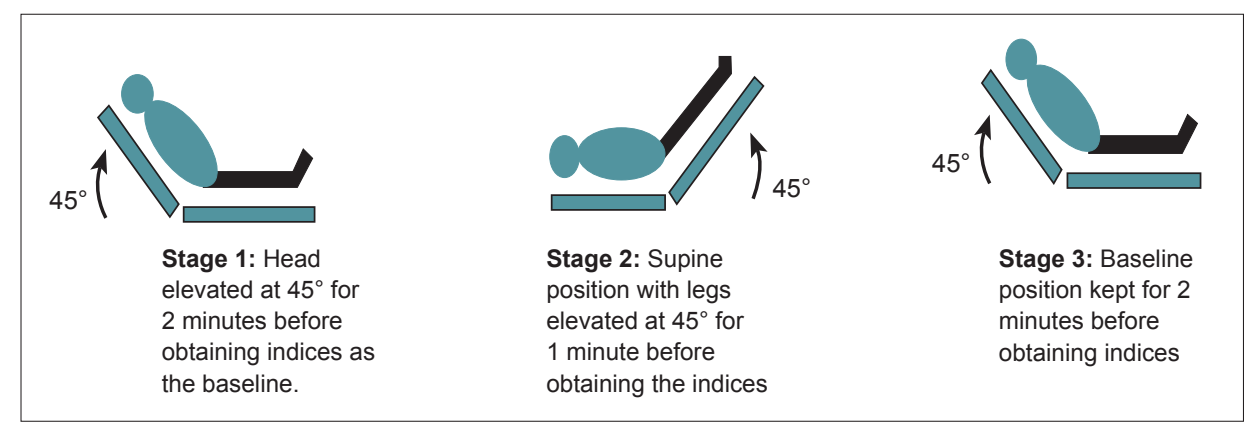

Figure 1. Study protocol. 
It was assumed that IVC-Cl would be clinically relevant if 95\% confidence interval of area under the curve (AUC) was $>0.75$, corresponding to AUC of good clinical tool as reported by Ray et al. ${ }^{[1]}$ Inclusion of 39 patients was required to achieve this purpose. Bootstrap analysis was used to calculate precise confidence intervals. Bootstrapping is a method for assigning measures of accuracy to sample estimates and allows estimation of the sampling distribution. ${ }^{\left[{ }^{12]}\right.}$ Five patients were added to account for possible missing data.

\section{RESULTS}

Total of 44 nonintubated, nonventilated, spontaneously breathing patients with sepsis were examined. Of those, 23 (52.3\%) patients were considered to be responders, with increase in $\mathrm{Cl}$ of $15 \%$ or more after PLR maneuver. There were no significant differences between responders and nonresponders with regard to demographic or baseline clinical characteristics (Table I).

Hemodynamic and ultrasonographic measurements are re-

Table I. Characteristics of the study population

\begin{tabular}{lccc}
\hline & Responders $(\mathbf{n}=\mathbf{2 3})$ & Non-responders $(\mathbf{n}=\mathbf{2}$ I) & $\mathbf{p}$ \\
\hline Age (years) & $64.65 \pm 11.28$ & $66.10 \pm 16.40$ & 0.734 \\
Gender (\% female) & 43.47 & 42.85 & 0.716 \\
Body mass index & $32.22 \pm 7.49$ & $33.14 \pm 7.56$ & 0.686 \\
APACHE II & $16(15.17)$ & $16(15.17)$ & 0.875 \\
SOFA & $8(7.10)$ & $9(8.10)$ & 0.146 \\
\hline
\end{tabular}

Data are presented as median $\left(Q_{1}, Q_{3}\right)$ where $Q_{1}$ : first quartile and $Q_{3}$ : third quartile. APACHE: Acute Physiology And Chronic Health Evaluation; SOFA: Sequential Organ Failure Assessment.

Table 2. Variations in hemodynamic parameters measured in responders and non-responders

\begin{tabular}{|c|c|c|c|}
\hline & Responders $(n=23)$ & Non-responders $(n=2 I)$ & $\mathbf{p}$ \\
\hline & Mean \pm SD & Mean $\pm S D$ & \\
\hline \multicolumn{4}{|c|}{ Heart rate (beats/minute) } \\
\hline Stage I & $83.35 \pm 5.88$ & $82.43 \pm 5.34$ & 0.231 \\
\hline Stage 2 & $81.78 \pm 5.38$ & $81.24 \pm 5.25$ & 0.736 \\
\hline Stage 3 & $84.87 \pm 5.83$ & $83.14 \pm 5.79$ & 0.342 \\
\hline \multicolumn{4}{|c|}{ Mean arterial pressure $(\mathrm{mmHg})$} \\
\hline Stage I & $68.22 \pm 5.83$ & $70.86 \pm 8.44$ & 0.451 \\
\hline Stage 2 & $76.57 \pm 7.23$ & $80.67 \pm 8.91$ & 0.100 \\
\hline Stage 3 & $67.43 \pm 5.37$ & $70.90 \pm 8.50$ & 0.464 \\
\hline \multicolumn{4}{|c|}{ Cardiac index (L/minute/M²) } \\
\hline Stage I & $2.26 \pm 0.11$ & $2.31 \pm 0.18$ & 0.326 \\
\hline Stage 2 & $3.03 \pm 0.17$ & $2.98 \pm 0.18$ & 0.287 \\
\hline Stage 3 & $2.30 \pm 0.12$ & $2.32 \pm 0.20$ & 0.756 \\
\hline \multicolumn{4}{|l|}{ IVC-CI (\%) } \\
\hline Stage I & $37.17 \pm 9.02$ & $25.29 \pm 8.25$ & $<0.00 I^{* * * *}$ \\
\hline Stage 2 & $|7.6| \pm 2.74$ & $17.62 \pm 2.87$ & 0.812 \\
\hline Stage 3 & $35.00 \pm 8.72$ & $26.05 \pm 7.56$ & $<0.00 I^{\text {wak }}$ \\
\hline \multicolumn{4}{|l|}{ IJV-Cl (\%) } \\
\hline Stage I & $39.04 \pm 8.42$ & $26.7 I \pm 7.04$ & $<0.00 I^{* * * *}$ \\
\hline Stage 2 & $18.83 \pm 2.84$ & $18.62 \pm 2.89$ & 0.990 \\
\hline Stage 3 & $38.61 \pm 8.74$ & $27.33 \pm 6.48$ & $0.001^{* * *}$ \\
\hline
\end{tabular}

Data are presented as median $\left(\mathrm{Q}_{1}, \mathrm{Q}_{3}\right)$ where $\mathrm{Q}_{1}$ : first quartile and $\mathrm{Q}_{3}$ : third quartile. " $\mathrm{p}<0.05$; ${ }^{* *} \mathrm{p}<0.0 \mathrm{I}$; ${ }^{* * a+k} \mathrm{p}<0.00 \mathrm{I}$. IVC-Cl: Inferior vena cava collapsibility index; IJV-Cl: Internal jugular vein collapsibility index; SD: Standard deviation. 
ported in Table 2. In 3 stages, heart rate (HR), mean arterial pressure (MAP), and $\mathrm{Cl}$ did not differentiate responders from non-responders. Responders had higher IJV-Cl and IVC-Cl than non-responders at stage I $(p<0.001)$. This difference was lost after the PLR maneuver at stage 2. Responders also had higher $\mathrm{I} \mathrm{V}-\mathrm{Cl}$ and $\mathrm{IVC}-\mathrm{Cl}$ than non-responders at stage 3 $(p=0.001, p<0.001$, respectively).

Total of I 32 paired measurements of $\mathrm{JV}-\mathrm{Cl}$ and IVC-CI were performed. On average, it took 47.5 seconds less to acquire $\mathrm{IJ}-\mathrm{Cl}$ measurements than paired IVC-Cl measurements. Mean time to data acquisition was 30 seconds (range: $25-45$

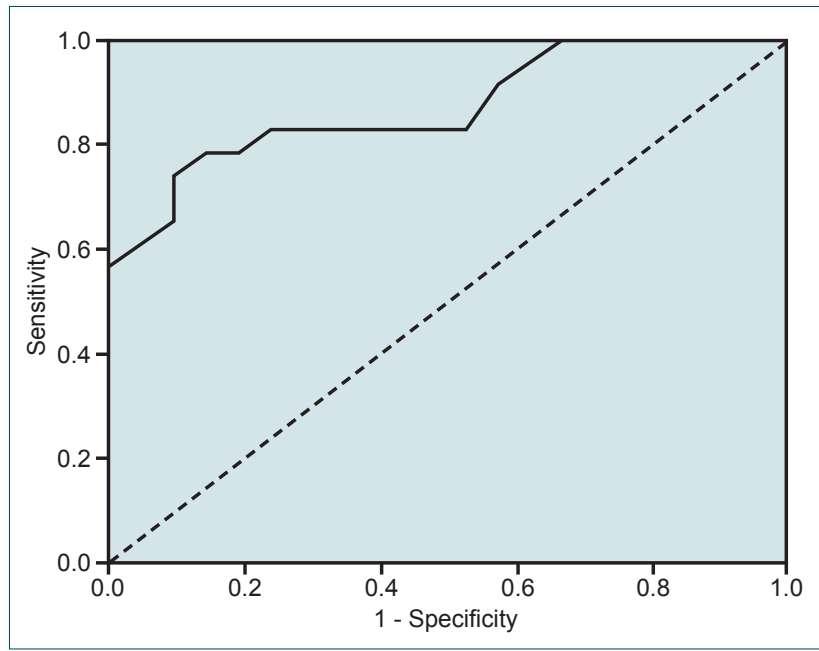

Figure 2. Receiver operating characteristic curve for discriminating responders from non-responders after passive leg raise. The solid line indicates area under curve for internal jugular vein collapsibility index at stage 1 of $0.825 ; p<0.001$.

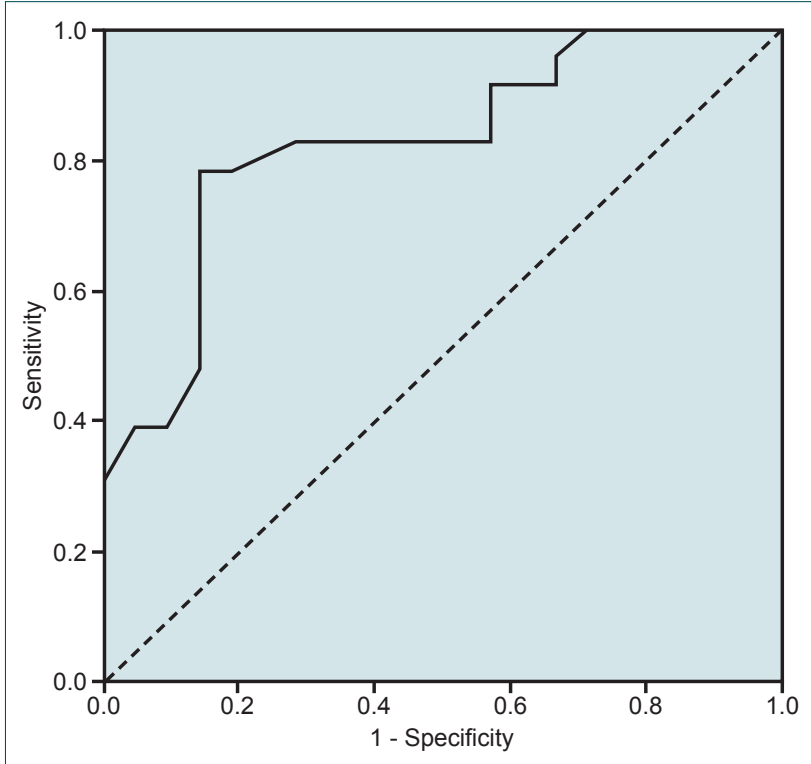

Figure 3. Receiver operating characteristic curve for discriminating responders from non-responders after passive leg raise. The solid line indicates area under curve for inferior vena cava collapsibility index at stage 1 of $0.825 ; p<0.001$. seconds) for $\mathrm{JV}-\mathrm{Cl}$ versus 77.5 seconds for IVC-Cl (range: 65 - 100 seconds; $\mathrm{p}<0.01$ ).

Cut-off values and corresponding sensitivity and specificities of $\mathrm{IJV}-\mathrm{Cl}$ at stage I were measured to distinguish responders and non-responders. Cut-off value was determined to be $\mathrm{JC}-\mathrm{Cl} \geq 36$ according to highest Youden index, with $0.78 \%$ sensitivity and $0.85 \%$ specificity. Area under the ROC curve (AUC) for IJV-Cl was 0.872 (Figure 2).

Cut-off values and corresponding sensitivity and specificities of IVC-Cl at stage I were measured to distinguish responders and non-responders. Cut-off value was determined to be IVC$\mathrm{Cl} \geq 35$ according to highest Youden index, with $0.78 \%$ sensitivity and $0.85 \%$ specificity. AUC for IVC-CI was 0.825 (Figure 3).

On linear regression analysis, paired measurements demon-

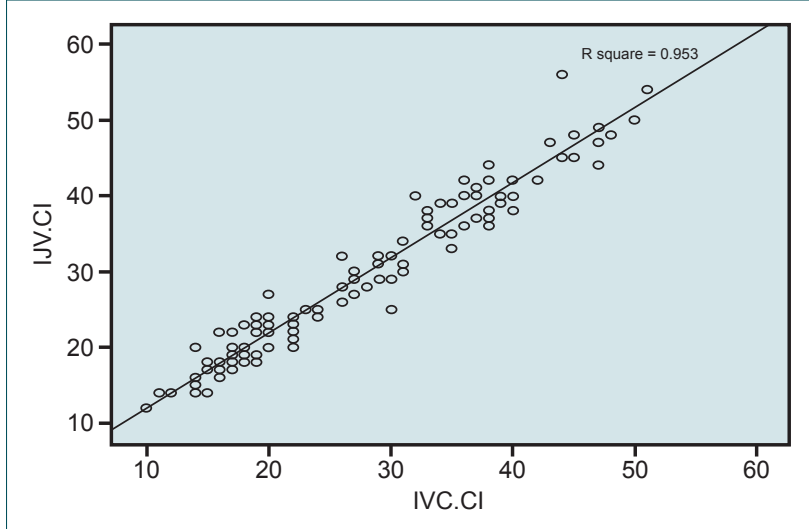

Figure 4. Inferior vena cava collapsibility index versus internal jugular vein collapsibility index. Linear regression demonstrates acceptable correlation between the 2 measurement modalities (R2=0.953). IJV-CI: Internal jugular vein collapsibility index; IVC$\mathrm{Cl}$ : Inferior vena cava collapsibility index.

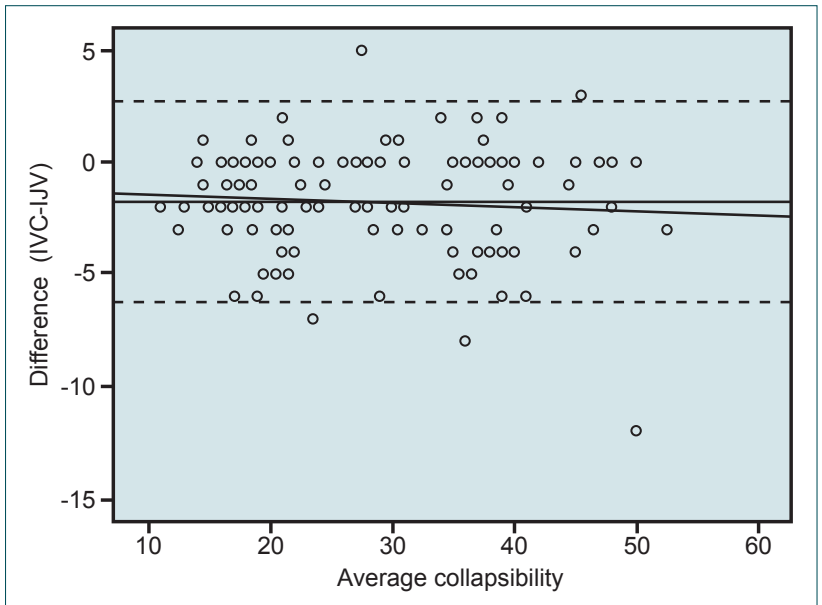

Figure 5. Measurement bias plot comparing inferior vena cava collapsibility index and internal jugular vein collapsibility index across a broad range of collapsibility values. IJV-CI: Internal jugular vein collapsibility index; IVC-CI: Inferior vena cava collapsibility index. 
strated acceptable correlation over a broad range of venous collapsibility values $\left(R^{2}=0.953\right.$; Figure 4$)$. As a result of the regression analysis, measurement bias was not observed on Bland-Altman graphics. Also, there was a positive correlation between IVC-Cl and IJV-Cl values $\left(r=0.976 ; \mathrm{R}^{2}: 0.953\right)$ (Figure 5).

\section{DISCUSSION}

Results of this study demonstrated that IJV collapsibility was a precise, easily acquired non-invasive parameter of fluid responsiveness in spontaneously breathing patients with sepsis and appeared to be a reasonable adjunct to IVC-CI. Additionally, it took less time to acquire $\mathrm{JV}-\mathrm{Cl}$ measurements than IVC-Cl measurements.

USCOM is a non-invasive continuous-wave (CW) Doppler ultrasound device, temporarily placed in the suprasternal notch to measure Doppler flow at the aortic valve over a cardiac cycle (velocity time integral, VTI). Valve cross-sectional area is determined by applying height-indexed regression equations, and then stroke volume is calculated by multiplying the VTI by the estimate of cross-sectional area. ${ }^{[13]}$

The Surviving Sepsis Campaign still recommends central venous pressure (CVP) as a guide for fluid infusion. ${ }^{[1]}$ However, right-sided filling pressure and CVP measurement require a central venous catheter, which delays resuscitation and is associated with numerous potential complications. ${ }^{[14]}$ Studies have concluded that there was good correlation between right atrial pressure and IVC respiratory variability in spontaneously breathing patients. ${ }^{[15,16]}$ Studies that compared IVC measurements and central venous pressure have reported that diameter of the IVC correlated directly to CVP in mechanically-ventilated patients with sepsis, and the IVC-Cl correlated with CVP in the setting of low and high $\mathrm{Cl}$ ranges. ${ }^{[8,17]}$ Brennan et al. demonstrated that cut-off value of $20 \%$ for passive IVC-Cl and cut-off value $40 \%$ in the sniff test were able to identify patients' right atrial pressure values less than and greater than $10 \mathrm{mmHg}{ }^{\left[{ }^{18]}\right.}$ Additionally, it has been shown that IVC variations were closely correlated with cardiac output increase after fluid infusion. ${ }^{[19,20]}$ Muller et al. analyzed respiratory variations of IVC to predict fluid responsiveness in spontaneously-breathing patients with acute circulatory failure. $^{[2 I]}$ The authors concluded that IVC-CI $>40 \%$ permitted the prediction of fluid responsiveness, but also IVC-CI $<40 \%$ did not rule out fluid needs.

A body of evidence shows that extrathoracic veins can reflect intrathoracic venous pressure and volume changes. ${ }^{[6,22]}$ Based on this association, we hypothesized that IJV-Cl could be an alternative sonographic option to IVC-Cl. Though several studies have examined IVC-Cl and IJV-Cl individually to evaluate intravascular volume status and CVP, scarce data exist on the relationship between IVC-Cl and IJV-Cl. One of our questions was whether IJV-Cl and IVC-Cl could be used interchangeably in the setting of spontaneous breathing. Kent et al. studied the feasibility of femoral vein (FV) or IJV collapsibility as options in intravascular volume status assessment and concluded that correlation between IVC-Cl and $\mathrm{FV} / \mathrm{IJV}-\mathrm{Cl}$ was weak. ${ }^{[23]}$ However, patients were predominately (72\%) mechanically ventilated in their study. Another study from the USA demonstrated that I $\mathrm{JV}-\mathrm{Cl}$ and IVC-Cl correlated during spontaneous breathing, but found no statistical correlation during increased thoracic and intra-abdominal pressure. ${ }^{[24]}$

PLR maneuver mimics an endogenous fluid challenge by transferring around $300 \mathrm{~mL}$ of venous blood from the lower body toward the right heart. ${ }^{[25]}$ PLR is a reversible maneuver, thereby avoiding the risks of volume overload. ${ }^{[26]}$ We assessed changes in $\mathrm{Cl}$ induced by PLR maneuver as an indicator of fluid responsiveness in patients with sepsis who were not receiving mechanical ventilation.

In the present study, IJV-Cl was measured to calculate a cutoff of $36 \%$, with sensitivity of $78 \%$ and specificity of $86 \%$ to predict volume response in spontaneously breathing patients with sepsis. Similarly, we also demonstrated IVC-CI threshold values of $35 \%$ to discriminate responders from non-responders with sensitivity of $78 \%$ and specificity of $86 \%$. As in our study, the literature has verified that IJV-Cl greater than $39 \%$ was strongly associated with overall patient hypovolemia. ${ }^{[27,28]}$

In the current study, cut-off values of similar parameters are somewhat higher than values reported in mandatory ventilated patients. ${ }^{[9,20,29]}$ Increased efficiency in patients not mechanically ventilated may result in decreased delta to intrathoracic pressure for comparable tidal volume, and so may require a larger signal to achieve a comparable effect. ${ }^{[30]}$

We excluded mechanically ventilated patients because net effect of intrathoracic pressure change may be difficult to assess and collapsibility index may be affected by the amount of diaphragmatic excursion vs. the amount of chest excursion. [31,32] These data suggest that collapsibility index poorly predicts volume responsiveness in this population.

Our study has several limitations. First, all measurements were performed by a single operator, interobserver variability in sonographic venous diameter measurement remains to be assessed in future studies. Secondly, we did not include patients with cardiac disease. Thirdly, changes in CVP influence IJV diameter and may decrease relative collapsibility. Increased intraabdominal or intrathoracic pressure may increase CVP, which can lead to reduced $\mathrm{JV}-\mathrm{Cl}$, independent of preload responsiveness. Of 44 enrolled patients, only 5 patients had CVP catheters. In that case, we did not study the effect of high CVP on IV-CI and IVC-CI. Therefore, in this study, any confounding conditions, such as cardiac disease, and increased thoracic and intraabdominal pressure were excluded. 
$\mathrm{J} \mathrm{V}-\mathrm{Cl}$ is a precise, easily acquired, non-invasive parameter of fluid responsiveness in spontaneously breathing patients with sepsis who are not mechanically ventilated. IJV-Cl also appears to be a reasonable adjunct to IVC-Cl. Furthermore, obtaining $\mathrm{IJV}-\mathrm{Cl}$ measurements requires less time than IVC-Cl measurements, which is another advantage.

\section{Conflict of interest: None declared.}

\section{REFERENCES}

1. Dellinger RP, Levy MM, Rhodes A, Annane D, Gerlach H, Opal SM, et al. Surviving Sepsis Campaign: international guidelines for management of severe sepsis and septic shock, 2012. Intensive Care Med 2013;39:165-228. [CrossRef]

2. Acheampong A, Vincent JL. A positive fluid balance is an independent prognostic factor in patients with sepsis. Crit Care 2015;19:251. [CrossRef]

3. Dellinger RP. Foreword. The Future of Sepsis Performance Improvement. Crit Care Med 2015;43:1787-9. [CrossRef]

4. Seif D, Perera P, Mailhot T, Riley D, Mandavia D. Bedside ultrasound in resuscitation and the rapid ultrasound in shock protocol. Crit Care Res Pract 2012;2012:503254. [CrossRef]

5. Nagdev AD, Merchant RC, Tirado-Gonzalez A, Sisson CA, Murphy MC. Emergency department bedside ultrasonographic measurement of the caval index for noninvasive determination of low central venous pressure. Ann Emerg Med 2010;55:290-5. [CrossRef]

6. Constant J. Using internal jugular pulsations as a manometer for right atrial pressure measurements. Cardiology 2000;93:26-30. [CrossRef]

7. Prekker ME, Scott NL, Hart D, Sprenkle MD, Leatherman JW. Pointof-care ultrasound to estimate central venous pressure: a comparison of three techniques. Crit Care Med 2013;41:833-41. [CrossRef]

8. Stawicki SP, Braslow BM, Panebianco NL, Kirkpatrick JN, Gracias $\mathrm{VH}$, Hayden GE, et al. Intensivist use of hand-carried ultrasonography to measure IVC collapsibility in estimating intravascular volume status: correlations with CVP. J Am Coll Surg 2009;209:55-61. [CrossRef]

9. Vieillard-Baron A, Chergui K, Rabiller A, Peyrouset O, Page B, Beauchet A, et al. Superior vena caval collapsibility as a gauge of volume status in ventilated septic patients. Intensive Care Med 2004;30:1734-9. [CrossRef]

10. Michard F, Boussat S, Chemla D, Anguel N, Mercat A, Lecarpentier Y, et al. Relation between respiratory changes in arterial pulse pressure and fluid responsiveness in septic patients with acute circulatory failure. Am J Respir Crit Care Med 2000;162:134-8. [CrossRef]

11. Ray P, Le Manach Y, Riou B, Houle TT. Statistical evaluation of a biomarker. The Journal of the American Society of Anesthesiologists 2010;112:1023-40. [CrossRef]

12. Carpenter J, Bithell J. Bootstrap confidence intervals: when, which, what? A practical guide for medical statisticians. Stat Med 2000;19:1141-64.

13. Nidorf SM, Picard MH, Triulzi MO, Thomas JD, Newell J, King ME, et al. New perspectives in the assessment of cardiac chamber dimensions during development and adulthood. J Am Coll Cardiol 1992;19:983-8.

14. Taylor RW, Palagiri AV. Central venous catheterization. Crit Care Med 2007;35:1390-6. [CrossRef]

15. Mintz GS, Kotler MN, Parry WR, Iskandrian AS, Kane SA. Real-time inferior vena caval ultrasonography: normal and abnormal findings and its use in assessing right-heart function. Circulation 1981;64:1018-25.

16. Moreno FL, Hagan AD, Holmen JR, Pryor TA, Strickland RD, Castle
$\mathrm{CH}$. Evaluation of size and dynamics of the inferior vena cava as an index of right-sided cardiac function. Am J Cardiol 1984;53:579-85. [CrossRef]

17. Schefold JC, Storm C, Bercker S, Pschowski R, Oppert M, Krüger A, et al. Inferior vena cava diameter correlates with invasive hemodynamic measures in mechanically ventilated intensive care unit patients with sepsis. J Emerg Med 2010;38:632-7. [CrossRef]

18. Brennan JM, Blair JE, Goonewardena S, Ronan A, Shah D, Vasaiwala S, et al. Reappraisal of the use of inferior vena cava for estimating right atrial pressure. J Am Soc Echocardiogr 2007;20:857-61. [CrossRef]

19. Feissel M, Michard F, Faller JP, Teboul JL. The respiratory variation in inferior vena cava diameter as a guide to fluid therapy. Intensive Care Med 2004;30:1834-7. [CrossRef]

20. Barbier C, Loubières Y, Schmit C, Hayon J, Ricôme JL, Jardin F, et al. Respiratory changes in inferior vena cava diameter are helpful in predicting fluid responsiveness in ventilated septic patients. Intensive Care Med 2004;30:1740-6. [CrossRef]

21. Muller L, Bobbia X, Toumi M, Louart G, Molinari N, Ragonnet B, et al. Respiratory variations of inferior vena cava diameter to predict fluid responsiveness in spontaneously breathing patients with acute circulatory failure: need for a cautious use. Crit Care 2012;16:R188. [CrossRef]

22. Sankoff J, Zidulka A. Non-invasive method for the rapid assessment of central venous pressure: description and validation by a single examiner. West J Emerg Med 2008;9:201-5.

23. Kent A, Patil P, Davila V, Bailey JK, Jones C, Evans DC, et al. Sonographic evaluation of intravascular volume status: Can internal jugular or femoral vein collapsibility be used in the absence of IVC visualization? Ann Thorac Med 2015;10:44,9.

24. Bauman Z, Coba V, Gassner M, Amponsah D, Gallien J, Blyden D, et al. Inferior vena cava collapsibility loses correlation with internal jugular vein collapsibility during increased thoracic or intra-abdominal pressure. J Ultrasound 2015;18:343-8. [CrossRef]

25. Jabot J, Teboul JL, Richard C, Monnet X. Passive leg raising for predicting fluid responsiveness: importance of the postural change. Intensive Care Med 2009;35:85-90. [CrossRef]

26. Monnet X, Rienzo M, Osman D, Anguel N, Richard C, Pinsky MR, et al. Passive leg raising predicts fluid responsiveness in the critically ill. Crit Care Med 2006;34:1402-7. [CrossRef]

27. Keller AS, Melamed R, Malinchoc M, John R, Tierney DM, Gajic O. Diagnostic accuracy of a simple ultrasound measurement to estimate central venous pressure in spontaneously breathing, critically ill patients. J Hosp Med 2009;4:350-5. [CrossRef]

28. Killu K, Coba V, Huang Y, Andrezejewski T, Dulchavsky S. Internal jugular vein collapsibility index associated with hypovolemia in the intensive care unit patients. Crit Ultrasound J 2010;2:13-7. [CrossRef]

29. Guarracino F, Ferro B, Forfori F, Bertini P, Magliacano L, Pinsky MR. Jugular vein distensibility predicts fluid responsiveness in septic patients. Crit Care 2014;18:647. [CrossRef]

30. Lanspa MJ, Grissom CK, Hirshberg EL, Jones JP, Brown SM. Applying dynamic parameters to predict hemodynamic response to volume expansion in spontaneously breathing patients with septic shock: reply. Shock 2013;39:462. [CrossRef]

31. MacIntyre NR. Respiratory function during pressure support ventilation. Chest 1986;89:677-83. [CrossRef]

32. Kimura BJ, Dalugdugan R, Gilcrease GW 3rd, Phan JN, Showalter BK, Wolfson $\mathrm{T}$. The effect of breathing manner on inferior vena caval diameter. Eur J Echocardiogr 2011;12:120-3. [CrossRef] 
ORİJINAL ÇALIŞMA - ÖZET

\section{Internal juguler ven kollabsibilite indeksinin sepsisteki değeri}

Dr. Murat Haliloğlu, Dr. Beliz Bilgili, Dr. Alper Kararmaz, Dr. İsmail Cinel

Marmara Üniversitesi Tıp Fakültesi, Anesteziyoloji ve Reanimasyon Anabilim Dalı, İstanbul

AMAÇ: Septik hastalarda sıvı yanıtını tahmin etmek için volüm durumunun hızlı, doğru ve tekrarlanabilir olarak değerlendirilmesi çok önemlidir. Spontan soluyan septik hastalarda sıvı yanıtının tahmininde inferiyor vena kava kollapsibilite indeksine (IVC-CI) ek olarak internal jugular ven kollapsibilite indeksinin (IJV-Cl) etkinliğini araştırmayı amaçladık.

GEREÇ VE YÖNTEM: Sonografik inceleme üç aşamada gerçekleştirildi. USCOM (Ultrasonic Cardiac Output Monitor) sistemiyle hemodinamik verilerle birlikte IVC-CI ve IJV-CI ölçümleri birinci aşamada yarı oturur pozisyonda, ikinci aşamada pasif bacak kaldırma sonrasında (PBK) ve üçüncü aşamada yeniden yarı oturur pozisyona getirildikten sonra ölçüldü. Sıvı yanıtı PBK sonrası kardiyak indeksdeki (CI) değişiklikle değerlendirildi. Hastalar retrospektif olarak iki gruba ayrıldı: PBK sonrası $\triangle \mathrm{Cl} \geq \%$ I5 olanlar sıvı yanıtlı $(\mathrm{R}), \Delta \mathrm{Cl}<\%$ I 5 sıvı yanıtsız olarak kabul edildi.

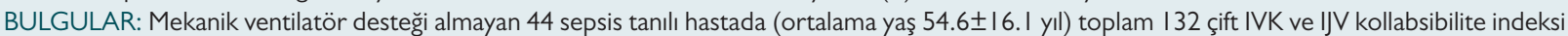
ölçümü yapıldı. Bu hastalardan 23'ü (\%52.2) yanıt alınan (R) olarak kabul edildi. Sıvı yanıtı alınan hastaların IJV-CI ve IVC-CI değerleri sıvı yanıtsız hastalara göre daha yüksekti $(p<0.00 I)$. İnternal jugular ven kollapsibilite indeksi değeri \%36 yüksek olması \%78 duyarlılı ve \%85 özgüllük ile sıvı yanıtlılığını tahmin edebilmektedir. Venöz çap ölçümleri için gereken zaman IJV-CI (30 sn), IVC-Cl (77.5 sn) karşılaştırıldığında IJV ölçüm süresi anlamlı olarak kısa bulundu $(\mathrm{p}<0.00 \mathrm{I})$.

TARTIŞMA: Mekanik ventilasyon desteği almayan septik hastalarda sıvı yanıtının tahmininde IJV-CI kolay uygulanabilen, invaziv olmayan bir parametredir, IVC-Cl yerine kullanılabilir.

Anahtar sözcükler: İnferiyor vena cava; internal juguler ven; kollabsibilite indeksi; sıvı yanıtı.

Ulus Travma Acil Cerrahi Derg 2017;23(4):294-300 doi: 10.5505/tjtes.2016.04832 